\title{
Licensing of Commensal Rodent Trappers ${ }^{1}$
}

\author{
Frederick M. Fishel ${ }^{2}$
}

The Florida Department of Agriculture and Consumer Services' Bureau of Licensing and Enforcement (FDACS BLE) administers Limited Certification Categories to certify Governmental or Private applicators. Limited certification programs available are for Commercial Landscape Maintenance, Lawn and Ornamental, Structural, and Urban Commercial Fertilizer applicators and Limited Commercial Wildlife Management trappers. This document will discuss the Limited Commercial Wildlife Management Trapper Certificate.

\section{Who is required to hold this certificate?}

Limited Commercial Wildlife Management Certification is required for any person who engages in the commercial trapping of wildlife-using nonchemical methods, including traps, glue boards, mechanical or electronic devices, and exclusionary techniques to control commensal rodents in, on, or under structures (Figure 1). Under this certificate, commensal rodents are referred to as rats and mice. FDACS requires that persons commercially trapping other nuisance wildlife species (e.g., raccoons, opossums, armadillos, skunks, squirrels) in, on, or under structures obtain a Pest Control Operator certificate in General Household Pests as outlined in Florida Statute 482.111. These structures can be residential, governmental, or commercial structures such as homes, schools, municipal/agency offices, banks, grocery stores, apartments, condominium common areas, hotels, restaurants, etc. Persons who are trapping wildlife on their own personal property do not need certification.

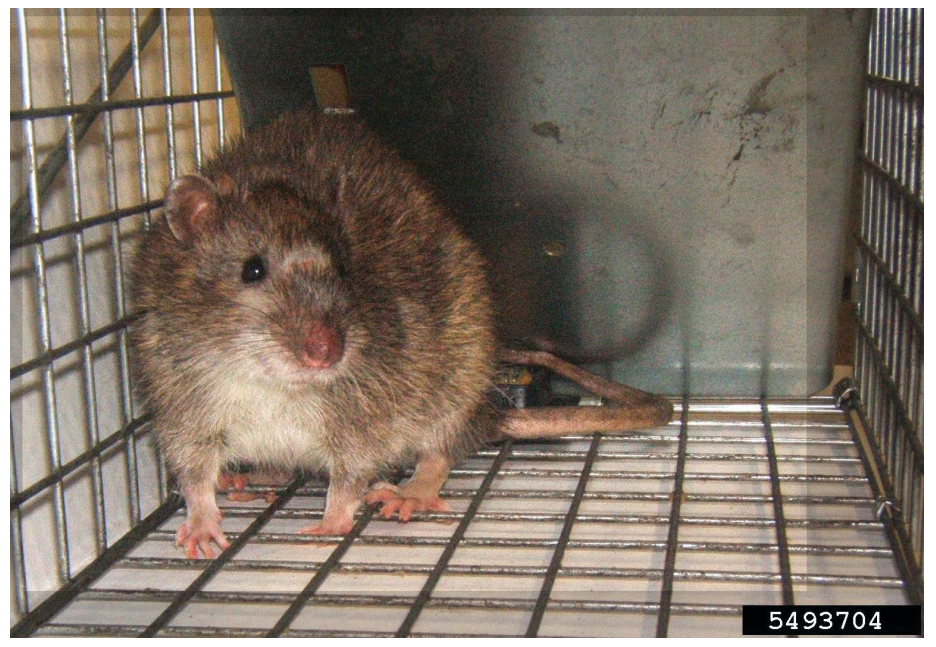

Figure 1. Rat captured in a box trap.

Credits: Liz Kasameyer, Johns Hopkins School of Public Health, Bugwood.org

\section{What are the limitations of this certificate?}

Limited Commercial Wildlife Management Certification does not authorize:

- The use of pesticides or chemical substances, other than adhesive materials, to control rodents or other nuisance wildlife in, on, or under structures;

- Operation of a pest control business; or

- Supervision of an uncertified person using nonchemical methods to control rodents

1. This document is PI278, one of a series of the Agronomy Department, UF/IFAS Extension. Original publication date October 2018. Visit the EDIS website at https://edis.ifas.ufledu for the currently supported version of this publication.

2. Frederick M. Fishel, professor, Agronomy Department; UF/IFAS Extension, Gainesville, FL 32611.

The Institute of Food and Agricultural Sciences (IFAS) is an Equal Opportunity Institution authorized to provide research, educational information and other services only to individuals and institutions that function with non-discrimination with respect to race, creed, color, religion, age, disability, sex, sexual orientation, marital status, national origin, political opinions or affiliations. For more information on obtaining other UF/IFAS Extension publications, contact your county's UF/IFAS Extension office. 


\section{Is there an exam that must be passed to obtain this certificate?}

Yes; a person seeking limited certification in Commercial Wildlife Management must pass an exam. The exam is offered online at select UF/IFAS Extension offices. For a listing of offices offering online exams, go to https://pesticideexam.ifas.ufl.edu/public/countyList.faces. The exam is also offered quarterly, or as necessary, in Apopka at the UF/ IFAS Mid Florida Research and Education Center located at 2725 South Binion Road, Apopka, Florida, 32703. The exam is composed of 30 multiple choice questions and a passing score of $70 \%$ is required.

\section{Are there study materials to prepare myself for the exam?}

Yes; see Table 1 for a listing and their sources.

Table 1. Study materials for the Limited Commercial Wildlife Management Certificate and their sources.

\begin{tabular}{|l|l|}
\hline \multicolumn{1}{|c|}{ Material } & \multicolumn{1}{c|}{ Source } \\
\hline Chapter 482, Florida Statutes & Download here \\
\hline Chapter 5E-14, Florida Administrative Code & Download here \\
\hline The Florida Mouse & Download here \\
\hline Rat and Mouse Control & Download here \\
\hline $\begin{array}{l}\text { Dealing with Unwanted Wildlife in an Urban } \\
\text { Environment }\end{array}$ & Download here \\
\hline Non-Chemical Rodent Control & Download here \\
\hline
\end{tabular}

\section{How do I apply to take the Limited Commercial Wildlife Management exam?}

Application is made to the BLE with the required fee, a check or money order in the amount of $\$ 150$ made payable to the Department of Agriculture and Consumer Services and, upon approval, an admission slip is provided to the applicant. Applications are taken either online at https:// aesecomm.freshfromflorida.com/ or mail at https://www. freshfromflorida.com/content/download/38299/853877/ limited_wildlife_pkt_072017.pdf.

\section{What are the insurance requirements for the Limited Commercial Wildlife Management Certificate?}

Prior to issuance of the Limited Commercial Wildlife Management certificate, proof of insurance is required. This is documented using a Certificate of Insurance (DACS Form 13688) that indicates that the employer meets the requirements for minimum financial responsibility for bodily injury and property damage consisting of:

- Bodily injury: $\$ 250,000$ each person and $\$ 500,000$ each occurrence; and property damage $\$ 250,000$ each occurrence and $\$ 500,000$ in the aggregate; or

- Combined single limit coverage: $\$ 500,000$ in the aggregate

\section{What are the renewal}

\section{requirements for the Limited Commercial Wildlife Management Certificate?}

The annual recertification must be accompanied by a fee of $\$ 75$ and proof of having obtained four hours of acceptable continuing education units (CEUs) submitted on DACS Form 13325 and proof of insurance. A total of 4 CEUs ( 2 core +2 category) are required for renewal. CEU opportunities are listed online at http://ceupublicsearch. freshfromflorida.com/. 